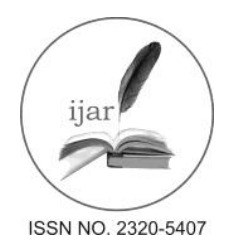

Journal homepage: http://www.journalijar.com
Journal DOI: 10.21474/IJAR01

INTERNATIONAL JOURNAL

OF ADVANCED RESEARCH

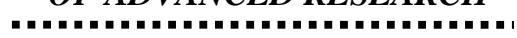

RESEARCH ARTICLE

\title{
ANTIMICROBIAL ACTIVITY OF MEIZOTROPIS PELLITA (PATWA) AGAINST GRAM'S POSITIVE AND GRAM'S NEGATIVE BACTERIA.
}

\author{
Neelam Rani ${ }^{1}$, Sanjeev Sharma ${ }^{2}$ and Mukta Sharma ${ }^{3}$. \\ 1. School of Engineering \& Technology, Ansal University, Gurgaon 122003, Haryana India. \\ 2. Shri Bankey Bihari Dental College and Research Centre, Masuri, Ghaziabad India.
}

\section{Manuscript Info}

Manuscript History:

Received: 19 February 2016

Final Accepted: 19 March 2016

Published Online: April 2016

Key words:

Meizotropis pellita, antimicrobial activity, agar well diffusion, MIC.

*Corresponding Author

Neelam Rani.

\begin{abstract}
Meizotropis pellita (Fabaceae family), an endangered plant commonly known as Patwa was screened for potential antimicrobial activity against medically important bacterial strains, namely Bacillus subtilis, Staphylococcus aureus Streptococcus pyogenes, Pseudomonas aeruginosa, Escherichia coli and Klebsiella pneumoniae. The antimicrobial activity was determined in alcoholic and aqueous extract using agar well diffusion method. The alcoholic extracts have shown antimicrobial activity while aqueous extract was inactive against all the tested bacterial strains. E.coli was the most resistant strain while Staphylococcus aureus and Streptococcus pyogenes were most sensitive bacterial strains. The results of the study suggest that the plant contain some important bioactive compounds which can be used for development of new herbal drugs.
\end{abstract}

Copy Right, IJAR, 2016.. All rights reserved.

\section{Introduction:-}

Medicinal plants are very good source of antimicrobial agents. Plant based drugs are used enormously in different countries and represents a class of many effective and valuable drugs. (Srivastava et al, 1996) Problems with drug resistance of microorganisms, side effects of modern drugs and emerging diseases where no medicines are available have created an ultimate need to discover new antimicrobial agents which are very effective with minimal side effects and have a great potential for the discovery of new antibiotic prototypes. (Musa et al, 2008). These opportunities through medicinal plant resources, and challenges in available therapeutic agents stimulated renewed interest in plants as significant source of new medicines. (Garg and Mohana, 2013)

Meizotropis pellita an angiosperm, belong to the family Fabaceae. This plant is a shrub with stout, woody perennial rootstock, from which several shoots erect up to 6 feet high and 0.75 inch diameter and are annually produced. It is commonly known as Patwa and is basically found in Patwadanger (Nainital District). It is an endangered plant and a lot of initiatives are in progress for the conservation of this plant (Singh et al, 2013). A survey of literature on Meizotropis pellita revealed that there is no report on antimicrobial activities of this plant but broad spectrum antimicrobial activities of family fabaceae have been reported. (Prabhakaran et al,2011, Hassen et al 2012 and Hossain et al, 2012). In this study the antimicrobial activities of the alcoholic and aqueous extracts were investigated to ascertain the scientific basis for the use of this plant against some pathogens.

\section{Materials and methods:- \\ Plant Material:-}

The fresh leaves of Meizotropis pellita (Patwa) was collected from Patwadanger, Nainital in the end of july . The leaves were washed thoroughly with tap water and then with distilled water. The plant material was shade dried for a couple of days and then dried in incubator at $37^{0} \mathrm{C}$ for 2-3 days. The dried leaves were then crushed in mechanical grinder till it becomes a fine powder and then it was stored in air tight container at room temperature. 


\section{Preparation of plant extract:-}

The extracts ( ethanolic, methanolic and aqueous) of the plant material were prepared by using cold maceration method. (Umeh et al 2005) $100 \mathrm{gm}$ of plant material were weighed in sterile bottle . the weighed plant material was then extracted with the solvents separately in tightly covered bottles and left for 2 days at room temperature. The resultant suspensions were filtered into sterile beakers and the filterate was refiltered using whatman filter paper no. 1 into sterile sample bottles.The extract was then concentrated and evaporated on rotary evaporator.

\section{Preparation of Stock solution of Extracts:-}

The crude extracts were diluted with $20 \%$ DMSO (Di methyl sulphoxide) solution to obtain $50 \mathrm{mg} / \mathrm{ml}, 25 \mathrm{mg} / \mathrm{ml}$, $12.5 \mathrm{mg} / \mathrm{ml}, 6.25 \mathrm{mg} / \mathrm{ml}$ and $3.12 \mathrm{mg} / \mathrm{ml}$ and they were stored properly in refrigerator (Akujobi et al.).

\section{Phytochemical Screening:-}

The alcoholic plant extracts of Meizotropis pellita was subjected to phytochemical screening for the presence of various compounds using standard procedures which revealed the presence of alkaloids, carbohydrates and proteins. (Silva et al. 1998 and Kalakoti et al 2015).

\section{Microorganisms Used:-}

Bacterial Strains were obtained from Microbial type Culture Collection (MTCC) and department of microbiology Shri Bankey Bihari Dental College and Research centre, Masuri, Ghaziabad. These includes three gram's positive bacterial species Bacillus subtilis (MTCC 441), Staphylococcus aureus (MTCC 96), Streptococcus pyogenes (MTCC 442) and three gram's negative species Pseudomonas aeruginosa (MTCC 424), Escherichia coli (MTCC 433 ) and Klebsiella pneumoniae (MTCC 1320)

\section{Antimicrobial Activity:-}

The Gram's positive and Gram's negative bacterial species were pre-cultured overnight in nutrient broth on a rotary shaker at $37^{\circ} \mathrm{C}$ and centrifuged at $10,000 \mathrm{rpm}$ for 5 minutes. Antimicrobial activity was tested against mentioned three Gram's positive and three Gram's negative bacterial strains, the testing was done by the modified agar well diffusion method. (Perez et al. 1990 and Adeshina et al. 2010). Muller Hinton agar (HiMedia Mumbai) was prepared as per the instructions by the manufacturer, once the media solidified then it was then inoculated with bacterial species. The media was then punched with $6 \mathrm{~mm}$ diameter hole and was filled with extract and control. DMSO was used as a negative control. The experiment was performed at different concentrations of the extracts (50 $3.12 \mathrm{mg} / \mathrm{ml}$ ). The test was carried out in triplicates to eliminate any error. The petridishes were incubated for $37^{0} \mathrm{C}$. The microbial growth was determined by measuring the diameter of zone of inhibition in millimeters around the well.

\section{Minimum Inhibitory Concentration:-}

The minimum inhibitory concentration (MIC) of the plant extract was determined by broth dilution technique. (Vollokova et al., 2001; Sidney et al., 1978). Two fold serial dilutions of the extract were made in the sterile broth to obtain the concentrations of 50, 25, 12.5, 6.25 and $3.12 \mathrm{mg} / \mathrm{ml}$, respectively. Mcfarland's turbidity scale no. 0.5 was prepared to give a turbid suspension of the microorganisms. Dilution of the test microbes was done in normal saline until the turbidity matches with that of the McFarland's scale by visual comparison. $0.1 \mathrm{ml}$ of each test microbe in the normal saline was then inoculated into the different concentrations. After incubation at $37^{\circ} \mathrm{C}$ for $24 \mathrm{~h}$, each test tube was observed for turbidity. The lowest concentration of the extract for which no turbidity was recorded was the minimum inhibition concentration (Osadebe and Okueze, 2004; Cowan, 1991).

Table 1: Antimicrobial activity of Ethanolic Extract of Meizotropis pellita against some Gram's positive and Gram's negative bacteria.

\begin{tabular}{|c|c|c|c|c|c|c|}
\hline \multirow{2}{*}{$\begin{array}{c}\text { Conc.of Extract } \\
(\mathrm{mg} / \mathrm{ml})\end{array}$} & \multicolumn{7}{|c|}{ Mean diameter zone of inhibition ( mm) } & \multicolumn{3}{c|}{} \\
\cline { 2 - 7 } & S.aureus & S. pyogenes & B.subtilis & P.aeruginosa & K.pneumoniae & E.coli \\
\hline 50 & 24 & 25 & 15 & 20 & 15 & 12 \\
\hline 25 & 21 & 23 & 13 & 18 & 14 & 10 \\
\hline 12.5 & 17 & 20 & 11 & 14 & 12 & NA \\
\hline 6.25 & 15 & 16 & NA & 10 & 10 & NA \\
\hline 3.12 & 11 & 12 & NA & NA & NA & NA \\
\hline
\end{tabular}


- NA - No activity

Table 2: Antimicrobial activity of Methanolic Extract of Meizotropis pellita against some Gram's positive and Gram's negative Bacteria.

\begin{tabular}{|c|c|c|c|c|c|c|}
\hline \multirow{2}{*}{$\begin{array}{c}\text { Conc.of Extract } \\
(\mathrm{mg} / \mathrm{ml})\end{array}$} & \multicolumn{7}{|c|}{ Mean diameter zone of inhibition $(\mathrm{mm})$} \\
\cline { 2 - 7 } & S.aureus & S. pyogenes & B.subtilis & P.aeruginosa & K.pneumoniae & E.coli \\
\hline 50 & 20 & 22 & 17 & 20 & 16 & 14 \\
\hline 25 & 18 & 20 & 14 & 20 & 14 & 12 \\
\hline 12.5 & 15 & 17 & 12 & 16 & 13 & NA \\
\hline 6.25 & 12 & 12 & 10 & 12 & 10 & NA \\
\hline 3.12 & 10 & 10 & NA & 10 & NA & NA \\
\hline
\end{tabular}

- $\quad \mathbf{N A}=$ No Activity

No antimicrobial activity was shown by the aqueous extract.

Table 3: The minimum inhibitory concentrations (M.I.C.) of the Ethanolic and Methanolic Extracts against the test microorganisms.

\begin{tabular}{|l|c|c|}
\hline Test Organism & Ethanol $\mathbf{( m g / m l )}$ & Methanol (mg/ml) \\
\hline Staphylococcus aureus & 1.56 & 1.56 \\
\hline Streptococcus pyrogenes & .781 & 1.56 \\
\hline Bacillus subtilis & 3.12 & 3.12 \\
\hline Pseudomonas aerugenosa & 6.25 & 3.12 \\
\hline Klebsiella pneumoniae & 6.25 & 6.25 \\
\hline E.coli & 25 & 25 \\
\hline
\end{tabular}

\section{Result and Discussion:-}

Meizotropis pellita showed inhibitorty activity in alcoholic extract and no activity towards aqueous extract. Based on the results it is concluded that plant extracts have very good potential as antimicrobial compounds against microorganisms and they can be used to treat various infectious diseases caused by resistant microorganisms. Streptococcus and Staphylococcus have shown distinguishable activity then the other bacterial strains. Therefore both can be used for further analysis. They can be used to discover bioactive herbal compound that may help in the discovery of new pharmaceuticals. Thus, the study ascertains that plant based drugs are the need for the future and could be of considerable interest in the development of new drugs.

\section{References:-}

1. Adeshina, G.O, Onaolapo, J.A., Olorunmola, E. and Odama, L.E. (2010): Phytochemical and antimicrobial studies of the ethylacetate extract of Alchornea cordifolia leaf found inAbuja, Nigeria.Journal of Medicinal Plants Research., 4(8): 649-658.

2. Akujobi, C., Anyanwu, B.N., Onyeze, C. and Ibekwe, V.I. (2004). Antibacterial and preliminary phytochemical screening of four medicinal plants. Journal of Applied Sciences. 7 (3): 4328 - 4338

3. Cowan MM (1999). Plants products as an antimicrobial agent's Clin. Microbiol. Rev. 12 (4) 564-582.

4. Garg, R. and Mohana, D.C. (2013). In vitro antibacterial activity and phytochemical analysis of some traditional herbs. Journal of Pharma and Bio Sciences., 4(1): 994-1003.

5. Hassen, T., Zanina, N., Neffati, M., Douki, W. and Nazzar, M.F. (2012):Cytotoxic and antibacterial activities of leaf extracts of Astragalus gombiformis Pomel (Fabaceae)growing wild in Tunisia. J. Biol. Tubitak., 36: 53-58.

6. Hossain, M.K., Hassan, M.M., Parvin, M.N., Hasan, M.M. and Islam, M.S., and Haque, M.A. (2012): Antimicrobial, cytotoxic and thrombolytic activity of Cassia senna leaves. Journal of applied pharmaceutical Science., 2 (6): 186-190.

7. Kalakoti, M. and Kumar, A.(2015): Phytochemical screening of leaf extract of Meizotropis pellita (Patwa) : An Endangered Plant Species. International journal of advance research. 3 (4): 361-365.

8. Musa, A.M., Abbas, G., Aliyu, A.B., Abdullahi, M.S. and Akpulu, I.N. (2008): Phytochemical and Antimicrobial Screening of Indigofera conferta GILLETT (Papilionaceae). Research journal of medicine., 2 (2): 74-78. 
9. Osadebe PO, Ukwueze SE (2004). A comparative study of the phytochemical and Antimicrobial properties of the Eastern Nigerian species of Africa Mistletoe (Loranthus micranthus) Sourced from different host trees. J. Beol. Res. Biotechnol. 2(1):18-23.

10. Perez, C., Pauli, M. and Bazerque, P. (1990). An antibiotic assay by agar-well diffusion method. Acta Biologiae et Medecine Experimentaalis, 15:113-115.

11. Prabakaran, M., Chandrakala, N., and Panneerselvam, A. (2011): Antimicrobial activity of Indigofera glandulosa (wild). Asian journal of plant science and research ., 1 (2): 18-25.

12. Sidney MF, Williaiam JM, Elvyn GS (1978). Baily and Scotts Microbiology. C. V. Moshy: st. Louis. pp 385403.

13. Silva, G.L., Lee, L. and Douglas, K. (1998): Special problems with the extraction of plants. Natural Products Isolation. 4: 343-363.

14. Singh, L., Nailwal, T.K., and Tiwari, L. (2013): An in Vitro Approach for the Conservation of Meizotropis pellita: An Endangered and Endemic Plant. American Journal of plant Sciences., 4: 1233-1240.

15. Srivastava, J., Lambert, J., and Vietmeyer,N. (1996) : Medicinal Plants : An expanding role in development. World bank technical paper. No. 320.

16. Umeh, E.U., Oluma, H.O.A., Igoli, J.O. (2005). Antibacterial screening of four local plants using an indicatorbased microdilution technique. Afr. J. Trad. 2(3): 238 -243.

17. Vollokova, AD, Kostalova, Sochorova (2001). Isoquinoline alkaloid from mahonia Aquifoluim stem bark is active against malseizia species. Fol. Microbiol 46:107-111. 